\title{
ANALISIS KINERJA ALGORITME TCP CONGESTION CONTROL BERDASARKAN SINGLE DAN MULTIPLE FLOW PADA MULTI-PATH ROUTING
}

\author{
Bayu Sutawijaya*1, Achmad Basuki², Fitra Abdurrachman Bachtiar ${ }^{3}$ \\ 1,2,3 Fakultas Ilmu Komputer, Universitas Brawijaya \\ Email: ${ }^{1}$ bayu.sutawijaya@student.ub.ac.id, ${ }^{2}$ abazh@ub.ac.id, ${ }^{3}$ fitra.bachtiar@ub.ac.id \\ *Penulis Korespondensi
}

(Naskah masuk: 19 Agustus 2019, diterima untuk diterbitkan: 05 Oktober 2020)

\begin{abstract}
Abstrak
Teknik multi-path routing merupakan solusi efektif untuk menambah kapasitas bandwidth jaringan. Namun, TCP menggunakan multiple paths sama dengan di single path. Penelitian ini melakukan analisis kinerja algoritme TCP congestion control Reno, BIC, CUBIC, dan BBR pada multi-path routing dengan setiap multiple paths menggunakan cost yang sama. Analisis yang dilakukan meliputi perbandingan antara single path routing dengan multi-path routing, single flow, dan multiple flow. Analisis single flow meliputi link delay dan loss rate. Sedangkan analisis multiple flow meliputi inter TCP protocol fairness dan fairness antara TCP dengan UDP. Semua evaluasi dilakukan berdasarkan emulasi pada VirtualBox. Berdasarkan hasil emulasi, multi-path routing dapat berdampak pada packet reordering, tetapi tidak mengakibatkan penurunan rata-rata throughput yang signifikan. Pada single flow, BBR merupakan algoritme TCP congestion control terbaik pada multi-path routing. Namun, pada multiple flow, CUBIC merupakan algoritme TCP congestion control terbaik pada multi-path routing. Pada evaluasi link delay, rata-rata RTT BBR lebih rendah hingga $58 \mathrm{~ms}$ dibandingkan dengan Reno, BIC, dan CUBIC. Sedangkan pada evaluasi loss rate, rata-rata throughput BBR lebih tinggi hingga $12 \mathrm{Mbps}$ dibandingkan dengan Reno, BIC, dan CUBIC. Pada evaluasi inter TCP protocol fairness dan fairness antara TCP dengan UDP, fairness CUBIC paling mendekati nilai 1 dibandingkan dengan Reno, BIC, dan BBR.
\end{abstract}

Kata kunci: kinerja TCP, TCP fairness, multi-path routing

\section{PERFORMANCE ANALYSIS OF TCP CONGESTION CONTROL ALGORITHMS BASED ON SINGLE AND MULTIPLE FLOW UNDER MULTI-PATH ROUTING}

\begin{abstract}
The multi-path routing technique is an effective solution to increase network bandwidth capacity. However, TCP uses multiple paths similar to a single path. This study analyzes the performance of TCP congestion control algorithms Reno, BIC, CUBIC, and BBR on multi-path routing with each multiple paths using the same cost. The analysis includes a comparison between single path routing and multi-path routing, single flow, and multiple flows. In a single flow, the analysis includes link delay and loss rate. Whereas in multiple flows, the analysis includes inter TCP protocol fairness and fairness between TCP and UDP. All evaluations are based on emulation in VirtualBox. Based on the results from emulation, multi-path routing can have an impact on packet reordering but does not result in a significant degrade in average throughput. In a single flow, BBR is the best TCP congestion control algorithm on multi-path routing. However, in multiple flows, CUBIC is the best TCP congestion control algorithm on multi-path routing. In the link delay evaluations, the average RTT on BBR up to $58 \mathrm{~ms}$ lower than Reno, BIC, and CUBIC. Whereas in the loss rate evaluations, the average throughput on BBR up to $12 \mathrm{Mbps}$ higher than Reno, BIC, and CUBIC. In the evaluation of inter TCP protocol fairness and fairness between TCP and UDP, fairness on CUBIC is closest to 1 than Reno, BIC, and BBR.
\end{abstract}

Keywords: TCP performance, TCP fairness, multi-path routing

\section{PENDAHULUAN}

Transmission Control Protocol (TCP) merupakan protokol transport yang paling banyak digunakan di jaringan Internet. TCP banyak digunakan karena kemampuan pengiriman TCP yang reliabel (Ros \& Welzl, 2013). Salah satu mekanisme dalam implementasi TCP yang paling penting dan kompleks adalah algoritme TCP congestion control (Carpa, dkk., 2017). Fungsi algoritme TCP congestion control adalah mengatur 
kecepatan pengiriman packet untuk mencegah congestion pada jaringan (Kurose \& Ross, 2017).

Namun, desain awal algoritme TCP congestion control adalah untuk single path routing (Carpa, dkk., 2017). Pada single path routing, pengiriman packet hanya dilakukan melalui satu jalur saja, walaupun Internet Service Provider (ISP) menyediakan dua atau lebih jalur menuju destination host. Untuk menambah kapasitas bandwidth jaringan, jalur-jalur yang disediakan oleh ISP dapat digunakan untuk load balancing trafik jaringan melalui teknik multi-path routing (Chaitanya \& Varadarajan, 2016).

Multi-path routing adalah teknik routing yang dilakukan dengan cara membagi trafik jaringan melalui multiple paths. Distribusi flow pada multipath routing dapat berbasis packet, yaitu sub-flow dikirimkan secara merata ke dalam multiple paths. Penggunaan multi-pah routing telah terbukti dapat meningkatkan throughput dan menurunkan RoundTrip Time (RTT) dibandingkan dengan single path routing (Liu, dkk., 2014; Kanagevlu \& Aung, 2015).

Namun, hanya sedikit yang dapat diketahui tentang dampak kinerja algoritme TCP congestion control pada multi-path routing. Multi-path routing dapat mengakibatkan packet reordering jika cost pada multiple paths berbeda. Packet reordering dapat mengakibatkan penurunan throughput pada algoritme TCP congestion control (Carpa, dkk., 2017; Karlsson, dkk., 2012). Oleh karena itu, perlu dilakukan analisis lebih lanjut kinerja algoritme TCP congestion control pada multi-path routing.

Kinerja algoritme TCP congestion control pada multi-path routing dipengaruhi oleh single flow dan multiple flow. Pada single flow, packet dikirimkan dari satu source host menuju satu destination host. Sedangkan pada multiple flow, packet dikirimkan dari dua atau lebih source host menuju dua atau lebih destination host. Kinerja algoritme TCP congestion control pada single flow dipengaruhi oleh link delay dan loss rate (Lukaseder, dkk., 2016). Sedangkan kinerja algoritme TCP congestion control pada multiple flow dipengaruhi oleh fairness antar algoritme TCP congestion control (inter TCP protocol fairness) dan fairness antara TCP dengan UDP (Yue, dkk., 2012; Kurose \& Ross, 2017).

Analisis single flow dan multiple flow telah dilakukan sebelumnya. Yue, dkk. (2012) melakukan evaluasi link delay, loss rate, dan inter TCP protocol fairnes. Kemudian, Arokkiam, dkk. (2014) melakukan evaluasi link delay dan fairness antara TCP dengan UDP. Sedangkan Lukaseder, dkk. (2016) melakukan evaluasi link delay, loss rate, dan inter TCP protocol fairness. Terakhir, Hock, Bless, \& Zitterbart. (2017) melakukan evaluasi link delay dan inter TCP protocol fairness. Namun, semua penelitian tersebut hanya dilakukan pada single path routing.

Oleh karena itu, penelitian ini melakukan analisis perbandingan kinerja beberapa algoritme
TCP congestion control pada multi-path routing. Setiap jalur pada multiple paths menggunakan cost yang sama karena kondisi tersebut merupakan kondisi terbaik pada multiple paths (Dixit, dkk., 2013). Analisis yang dilakukan meliputi perbandingan antara single path routing dengan multi-path routing, link delay, loss rate, inter TCP protocol fairness, dan fairness antara TCP dengan UDP. Algoritme TCP congestion control yang dilakukan perbandingan adalah Reno (Jacobson, 1990), Binary Increase Congestion Control (BIC) (Xu, Harfoush, \& Rhee, 2004), CUBIC (Ha, Rhee, $\& \mathrm{Xu}, 2008)$, dan Bottleneck Bandwidth and Roundtrip propagation time (BBR) (Cardwell dkk., 2016a). Reno, BIC, dan CUBIC merupakan algoritme TCP congestion control yang paling banyak digunakan pada sistem operasi sampai saat ini. Sedangkan BBR merupakan algoritme TCP congestion control yang paling baru untuk saat ini.

\section{METODE PENELITIAN}

\subsection{Perancangan Testbed}

Untuk melakukan evaluasi kinerja algoritme TCP congestion control pada multi-path routing, maka dilakukan pembuatan testbed. Testbed dibuat dengan menggunakan virtual machine (VM) pada VirtualBox (VirtualBox, n.d.). VirtualBox berjalan pada komputer dengan spesifikasi CPU Intel Core i5-7200U dan RAM 8 GB. Testbed pada penelitian ini menggunakan $8 \mathrm{VM}$ yang terdiri dari 4 host, 2 router, dan 2 switch. Semua VM disusun sehingga membentuk topologi seperti pada Gambar 2. Setiap VM dihubungkan dengan virtual ethernet. Sistem operasi yang digunakan semua VM adalah Ubuntu Server 16.04 dengan Linux Kernel 4.15. Setiap VM menggunakan CPU 1 core dan RAM 768 MB. Khusus pada router 1 menggunakan RAM 2 GB karena router 1 digunakan untuk capture TCP packet. Kemudian, setiap interface pada semua VM menggunakan Intel PRO/1000 MT Desktop.

Switch diimplementasikan pada setiap multiple paths untuk melakukan emulasi cost. Masingmasing switch menggunakan cost yang sama. Cost yang digunakan adalah bottleneck bandwidth, link delay, loss rate, dan ukuran buffer. Emulasi bottleneck bandwidth dilakukan dengan menggunakan Token Bucket Filter (TBF) (Kuznetsov, n.d.) sebesar 10 Mbps. Konfigurasi TBF dilakukan pada kedua interface setiap switch. Bandwidth antara host dengan router adalah bandwidth default sistem VirtualBox, yang setelah dilakukan pengukuran adalah 2.4 Gbps. Oleh karena itu, bandwidth maksimum pada saat pengiriman packet dari source host menuju destination host dibatasi oleh konfigurasi TBF.

Selanjutnya, untuk melakukan emulasi link delay, loss rate, dan ukuran buffer pada switch, penelitian ini menggunakan NetEM (NetEM, n.d.). Konfigurasi link delay pada semua evaluasi adalah 
sebesar $10 \mathrm{~ms}$, kecuali pada evaluasi variasi link delay yang mengikuti skenario evaluasi. Link delay pada penelitian ini merupakan representasi dari twoway propagation delay antara router 1 dan router 2 . Oleh karena itu, untuk melakukan emulasi link delay $10 \mathrm{~ms}$, setiap interface switch dilakukan konfigurasi sebesar 5 ms. Sedangkan link delay antara host dan router merupakan link delay default dari sistem VirtualBox, yang setelah dilakukan pengukuran adalah $0.1 \mathrm{~ms}$. Oleh karena itu, delay antara source

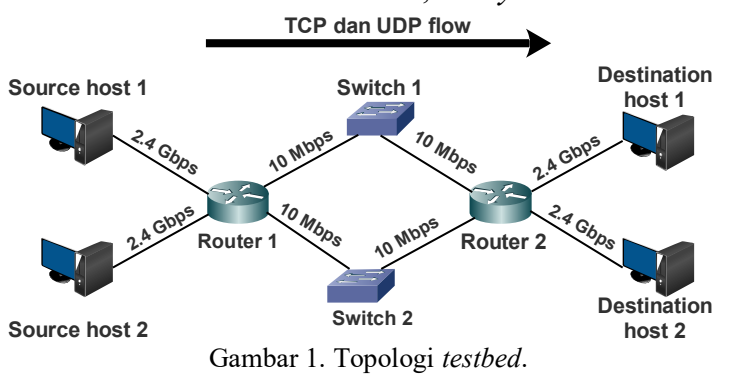

host dengan destination host lebih dipengaruhi oleh emulasi link delay pada NetEM. Selanjutnya, untuk konfigurasi loss rate akan disesuaikan dengan skenario evaluasi. Sedangkan konfigurasi ukuran buffer setiap switch adalah 100 packet.

Setiap switch terhubung dengan dua router yang berfungsi untuk melakukan multi-path routing. Jumlah jalur yang digunakan untuk multi-path routing adalah dua jalur. Untuk mendistribusikan packet ke dalam multiple paths, maka penelitian ini menggunakan True (or Trivial) Link Equalizer (TEQL) (Hubert, dkk., 2002). TEQL mendistribusikan packet secara merata ke dalam multiple paths berdasarkan round-robin. Roundrobin cocok digunakan pada multiple paths yang menggunakan cost sama (Singh, Das, \& Jukan, 2015).

Setiap router terhubung dengan host yang digunakan untuk evaluasi algoritme TCP congestion control. Penelitian ini menggunakan 4 host, yaitu 2 source host dan 2 destination host. Pada setiap host, dilakukan pengaktifan Selective Acknowledgment (SACK), Duplicate SACK (DSACK), timestamp, dan window scaling option.

Untuk melakukan observasi kinerja algoritme TCP congestion control pada multi-path routing, maka untuk mengaktifkan Reno, BIC, CUBIC, dan BBR cukup dilakukan pada source host (Cardwell, dkk., 2016). CUBIC merupakan algoritme TCP congestion control default di Linux Kernel 4.15. Untuk mengaktifkan Reno, BIC, dan BBR, dilakukan dengan mengaktifkan modul Reno, BIC, dan BBR pada Linux. Parameter yang digunakan Reno, BIC, CUBIC, dan BBR adalah parameter default dari Linux Kernel 4.15. Khusus pada BBR, dilakukan tambahan konfigurasi, yaitu mengaktifkan fair queuing pada source host (Cheng \& Cardwell, 2016).

\subsection{Pengukuran Kinerja}

Untuk mengukur kinerja Reno, BIC, CUBIC, dan BBR pada jaringan multi-path routing, maka evaluasi dilakukan berdasarkan parameter pada Tabel 1. Untuk semua evaluasi, pengiriman TCP/UDP flow dilakukan dengan menggunakan iPerf3 (iPerf, n.d.) selama 100 detik. Selama evaluasi berlangsung, dilakukan capture TCP packet dengan menggunakan Tcpdump (Tcpdump, n.d.) sebagai bahan analisis. Evaluasi dilakukan berdasarkan tiga skenario, yaitu perbandingan

\begin{tabular}{|c|c|}
\hline Parameter & Deskripsi \\
\hline Waktu evaluasi & 100 detik \\
\hline $\begin{array}{c}\text { TCP dan UDP packet } \\
\text { generator }\end{array}$ & iPerf3 \\
\hline Packet monitoritng & Tcpdump \\
\hline Skenario evaluasi & $\begin{array}{l}\text { Perbandingan antara single path } \\
\text { routing dengan multi-path } \\
\text { routing, link delay, loss rate, } \\
\text { inter TCP protocol fairness, dan } \\
\text { fairness antara TCP dengan UDP }\end{array}$ \\
\hline Perulangan evaluasi & 10 kali \\
\hline Parameter evaluasi & $\begin{array}{l}\text { Throughput, RTT, SACK } \\
\text { blocks, Jain's fairness index }\end{array}$ \\
\hline
\end{tabular}

antara single path routing dengan multi-path routing, single flow, dan multiple flow. Untuk menjaga tingkat akurasi, maka setiap skenario evaluasi dilakukan perulangan sebanyak 10 kali.

Evaluasi pertama adalah perbandingan antara single path routing dengan multi-path routing. Evaluasi dilakukan dengan mengirimkan satu TCP flow dari source host 1 menuju destination host 1 . TCP flow pertama dikirimkan melalui satu jalur (single path routing), sedangkan TCP flow kedua dikirimkan melalui dua jalur (multi-path routing). Algoritme TCP congestion control Reno, BIC, CUBIC, dan BBR dilakukan evaluasi secara bergantian. Berdasarkan hasil evaluasi, kemudian dilakukan perbandingan jumlah SACK blocks dan rata-rata throughput Reno, BIC, CUBIC, dan BBR antara single path routing dengan multi-path routing.

Evaluasi kedua adalah single flow yang dilakukan dengan cara mengirimkan satu TCP flow ke dalam multiple paths. TCP flow dikirimkan dari source host 1 menuju destination host 1 . Pada evaluasi single flow, kinerja yang diukur adalah ratarata throughput dan rata-rata RTT. Kinerja single flow diukur berdasarkan 2 skenario evaluasi yaitu:

1) Variasi link delay: Evaluasi dilakukan berdasarkan variasi link delay $10 \mathrm{~ms}-100 \mathrm{~ms}$ dengan kelipatan $10 \mathrm{~ms}$ untuk setiap pengukuran kinerja. Algoritme TCP congestion control Reno, BIC, CUBIC, dan BBR dilakukan evaluasi secara bergantian untuk setiap variasi link delay.

2) Variasi loss rate: Evaluasi dilakukan berdasarkan variasi loss rate $1 \%-10 \%$ dengan 
kelipatan $1 \%$ untuk setiap pengukuran kinerja. Loss rate hanya dilakukan pada saat pengiriman packet dari source host menuju destinaton host. Algoritme TCP congestion control Reno, BIC, CUBIC, dan BBR dilakukan evaluasi secara bergantian untuk setiap variasi loss rate.

Evaluasi ketiga adalah multiple flow yang dilakukan dengan cara mengirimkan dua flow ke dalam multiple paths. Flow pertama dikirimkan dari source host 1 menuju destination host 1, dan flow kedua dikirimkan dari source host 2 menuju destination host 2. Kinerja multiple flow diukur berdasarkan 2 skenario evaluasi, yaitu:

\begin{tabular}{ccc}
\multicolumn{3}{c}{ Tabel 2. Konfigurasi host inter TCP protocol fairness } \\
\hline Evaluasi & Source host 1 & Source Host 2 \\
\hline 1 & CUBIC & Reno \\
2 & BIC & CUBIC \\
3 & BIC & Reno \\
4 & BBR & CUBIC \\
5 & BBR & Reno \\
6 & BBR & BIC \\
\hline
\end{tabular}

1) Inter TCP protocol fairness: Evaluasi dilakukan dengan mengirimkan dua TCP flow dengan setiap flow menggunakan algoritme TCP congestion control yang berbeda. Source host 1 mengirimkan TCP flow dari detik ke $1-100$ dan source host 2 mengirimkan TCP flow dari detik ke 6 - 100. Konfigurasi algoritme TCP congestion control pada source host 1 dan source host 2 untuk setiap evaluasi dilakukan berdasarkan Tabel 2.

2) Fairness antara TCP dengan UDP: Evaluasi dilakukan dengan source host 1 mengirimkan TCP flow dari detik ke $1-100$ dan source host 2 mengirimkan UDP flow dari detik ke 6-100. Pengiriman UDP flow dilakukan berdasarkan variasi constant bit rate (CBR) $2 \mathrm{Mbps}-20 \mathrm{Mbps}$ dengan kelipatan 2 Mbps untuk setiap pengukuran kinerja. Algoritme TCP congestion control Reno, BIC, CUBIC, dan BBR dilakukan evaluasi secara bergantian untuk setiap variasi CBR.

Pada multiple flow, kinerja yang diukur adalah fairness. Fairness dihitung berdasarkan Jain's fairness index (Jain, Chiu, \& Hawe, 1984) pada persamaan (1). Pada persamaan (1), $x_{i}$ merupakan throughput dari flow i dengan total flow n. Jain's fairness index memiliki rentang nilai $0-1$. Algoritme TCP congestion control dikatakan mendapatkan fairness paling tinggi jika Jain's fairness index bernilai 1 .

$$
J\left(x_{1}, x_{2}, \ldots, x_{n}\right)=\frac{\left(\sum_{i=1}^{n} x_{i}\right)^{2}}{n * \sum_{i=1}^{n} x_{i}^{2}}, \quad J \in[0,1]
$$

\section{PERILAKU TCP CONGESTION CONTROL PADA MULTI-PATH ROUTING}

\subsection{Algoritme TCP Congestion Control}

Algoritme TCP congestion menggunakan mekanisme congestion (cwnd) untuk menentukan jumlah pengiriman packet. Apabila bandwidth jaringan masih tersedia, algoritme TCP congestion control menaikkan cwnd. Namun, jika jaringan mengalami congestion, maka algoritme TCP congestion control menurunkan cwnd untuk mencegah congestion terjadi terusmenerus (Kurose \& Ross, 2017). Algoritme TCP congestion control yang digunakan pada penelitian ini adalah sebagai berikut.

1) Reno

Reno menggunakan teknik Additive Increase Multiplicative Decrease (AIMD) untuk menentukan ukuran cwnd. Pada additive increase, Reno menaikkan cwnd sebesar 1 packet untuk setiap RTT. Apabila terjadi packet loss, Reno menjalankan multiplicative decrease, yaitu menurunkan cwnd sebesar setengah (Jacobson, 1990).

2) $\mathrm{BIC}$

BIC menggunakan tiga fase untuk menentukan ukuran cwnd, yaitu additive increase, binary search increase, dan slow start max probing. Apabila jarak antara cwnd dengan titik packet loss masih jauh, BIC melakukan fase additive incrase, yaitu menaikkan cwnd secara agresif. Kemudian, jika cwnd mendekati titik packet loss, maka BIC melakukan fase binary search increase, yaitu menurunkan keagreasifan dalam menaikkan cwnd. Apabila cwnd lebih tinggi dari titik packet loss yang sebelumnya, maka BIC mengindikasikan terjadi perubahan pada bandwidth jaringan. Oleh karena itu, BIC melakukan fase slow start max probing, yaitu menaikkan cwnd secara agresif untuk mencari titik packet loss yang baru. (Xu, Harfoush, \& Rhee, 2004).

3) CUBIC

CUBIC memulai pengiriman packet melalui fase hybrid slow start (Ha \& Rhee, 2008), yaitu menaikkan cwnd secara agresif dan berhenti jika memenuhi salah satu dari dua kondisi. Kondisi pertama adalah pada saat cwnd mencapai estimasi BDP. Kondisi kedua adalah pada saat delay mengalami kenaikan yang signifikan dibandingkan dengan delay yang sebelumnya. Kemudian, CUBIC melakukan fase congestion avoidance. Pada fase congestion avoidance, CUBIC menaikkan cwnd berdasarkan fungsi cubic (Ha, Rhee, \& Xu, 2008).

4) BBR

BBR menggunakan estimasi dari Bandwidth Delay Product (BDP) untuk menentukan ukuran cwnd. Estimasi BDP pada BBR merupakan estimasi dari bottleneck bandwidth maksimum dan RTT minimum jaringan. BBR menaikkan cwnd berdasarkan empat fase. Fase pertama adalah startup, yaitu menaikkan cwnd secara agresif sampai titik BDP jaringan. Fase kedua adalah drain, yaitu menurunkan cwnd karena fase startup mengakibatkan packet BBR mengisi buffer. Fase ketiga adalah probe bandwidth untuk melakukan estimasi bottleneck bandwidth maksimum. Fase keempat adalah probe RTT untuk melakukan estimasi RTT minimum (Cardwell, dkk., 2017). 
Gambar 2 menunjukkan perbandingan perilaku perubahan cwnd terhadap BDP untuk TCP Reno, BIC, CUBIC, dan BBR pada lingkungan pengujian dengan link delay $100 \mathrm{~ms}$, loss rate 0\%, dua link paths dengan bandwidth masing-masing $10 \mathrm{Mbps}$ (kumulatif 20 Mbps). Reno, BIC, dan CUBIC menaikkan cwnd secara bertahap untuk mencapai kapasitas maksimum bandwidth jaringan. Apabila cwnd Reno, BIC, dan CUBIC telah mencapai kapasitas bandwidth maksimum jaringan, packet Reno, BIC, dan CUBIC mulai mengisi buffer, seperti yang ditunjukkan pada saat ukuran cwnd lebih tinggi dibandingkan dengan BDP. Reno, BIC, dan CUBIC terus mengisi buffer sampai mendeteksi packet loss karena buffer terisi penuh. Pada saat jumlah packet loss melebihi batas toleransi, Reno, BIC, dan CUBIC menurunkan cwnd karena Reno, BIC, dan CUBIC mendeteksi packet loss sebagai tanda congestion pada jaringan.

Namun, pada saat pengujian selama 100 detik, BIC dan CUBIC lebih sering mengalami packet loss dibandingkan dengan Reno. Penyebabnya adalah BIC dan CUBIC tidak menurunkan ukuran window sedrastis Reno pada saat terjadi packet loss. Selain itu, BIC dan CUBIC menaikkan cwnd lebih agresif dibandingkan dengan Reno. Oleh karena itu, BIC dan CUBIC membutuhkan waktu yang lebih pendek dibandingkan dengan Reno untuk menaikkan cwnd sampai terjadi packet loss.

Sebaliknya, BBR mendefinisikan congestion pada saat packet mulai mengisi buffer. Pada saat awal pengiriman packet, BBR menaikkan cwnd secara agresif untuk melakukan pencarian BDP jaringan. Kenaikan cwnd secara agresif tersebut dapat mengakibatkan BBR mengalami packet loss.

Setelah BBR melakukan estimasi BDP, BBR menjaga ukuran cwnd di sekitar BDP. Kemudian, BBR secara berkala melakukan estimasi BDP kembali. Untuk melakukan estimasi bottleneck bandwidth, BBR menaikkan cwnd. Apabila bottleneck bandwidth tidak berubah, cwnd BBR akan sedikit lebih tinggi dibandingkan dengan BDP. Kemudian, untuk melakukan estimasi RTT, BBR menurunkan cwnd secara drastis.

\subsection{Multi-path Routing}

Penggunaan algoritme TCP congestion control pada multi-path routing dapat mengakibatkan packet reordering. Packet reordering dapat disebabkan oleh perbedaan link delay, perbedaan ukuran packet, dan perbedaan waktu transmisi (Dixit dkk., 2013). Packet reordering dapat berdampak pada perilaku dan kinerja algoritme TCP congestion control, yaitu:

1) Packet rerdering dapat menyebabkan algoritme TCP congestion control mendeteksi packet reordering sebagai packet loss. Oleh karena itu, packet reordering dapat mengakibatkan algoritme TCP congestion control berbasis packet loss menurunkan ukuran cwnd sebelum bandwidth jaringan terisi penuh (Bennett, Partridge, \& Shectman, 1999).
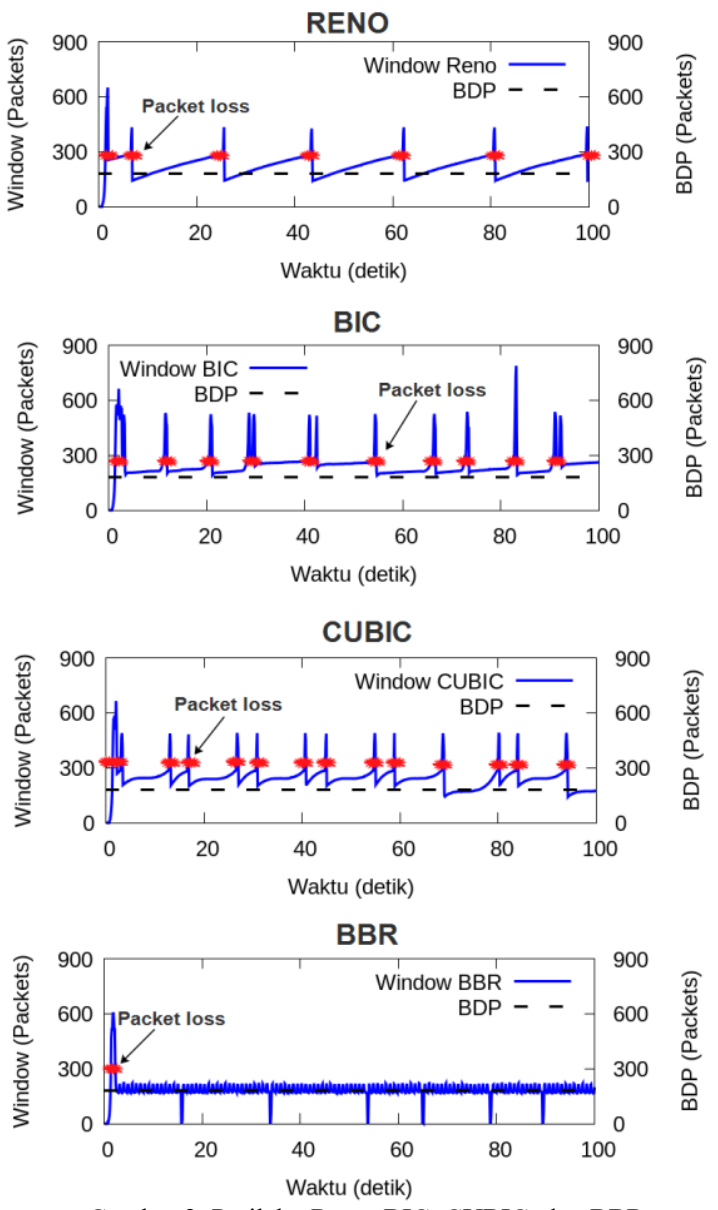

Gambar 2. Perilaku Reno, BIC, CUBIC, dan BBR

2) Packet reordering dapat memicu algoritme TCP congestion control melakukan retransmission, walaupun tidak terjadi packet loss. Oleh karena itu, packet yang sama akan dikirimkan dua kali (Bennett, Partridge, \& Shectman, 1999).

Linux memiliki mekanisme untuk mengatasi permasalahan packet reordering. Namun, mekanisme pada Linux dapat bekerja dengan baik jika link delay pada multiple paths hanya berbeda sedikit dan source host menerima ACK secara urut (Karlsson, dkk., 2012; Carpa, dkk., 2017).

\section{HASIL EVALUASI DAN PEMBAHASAN}

\subsection{Perbandingan Antara Single Path Routing dengan Multi-path Routing}

Evaluasi ini dilakukan untuk mengetahui perbedaan perilaku dan kinerja Reno, BIC, CUBIC, dan BBR antara single path routing dengan multipath routing. Tabel 3 menunjukkan perbandingan jumlah SACK blocks dan rata-rata throughput Reno, BIC, CUBIC, dan BBR antara single path routing dengan multi-path routing. Pada multi-path routing, jumlah SACK blocks Reno, BIC, CUBIC, dan BBR mengalami peningkatan yang signifikan 
dibandingkan dengan single path routing, yaitu lebih dari 11 kali lipat. Pada single path routing, destination host hanya mengirimkan SACK blocks pada saat terjadi packet loss. Namun, pada multipath routing, destination host terus-menerus mengirimkan SACK blocks selama 100 detik, walaupun tidak pada saat terjadi packet loss.

Tabel 3. Perbandingan single path routing dan multi-path routing

\begin{tabular}{ccccc}
\hline \multirow{2}{*}{ TCP } & \multicolumn{2}{c}{ Single path routing } & \multicolumn{2}{c}{ Multi-path routing } \\
\cline { 2 - 5 } & $\begin{array}{c}\text { SACK } \\
\text { blocks }\end{array}$ & $\begin{array}{c}\text { Throughput } \\
\text { (Mbps) }\end{array}$ & $\begin{array}{c}\text { SACK } \\
\text { blocks }\end{array}$ & $\begin{array}{c}\text { Throughput } \\
\text { (Mbps) }\end{array}$ \\
\hline Reno & 1780 & 9.57 & 73263 & 19.1 \\
BIC & 12089 & 9.57 & 129205 & 19.14 \\
CUBIC & 4541 & 9.57 & 177040 & 19.08 \\
BBR & 0 & 9.45 & 70380 & 18.69 \\
\hline
\end{tabular}

Fenomena SACK blocks pada multi-path routing menunjukkan bahwa multi-path routing dapat mengakibatkan packet reordering, walaupun multiple paths menggunakan cost yang sama dan TEQL mendistribusikan packet secara merata. Packet reordering yang terjadi pada penelitian ini disebabkan oleh sedikit perbedaan waktu pengiriman packet antara switch 1 dengan switch 2

Namun, rata-rata throughput Reno, BIC, CUBIC, dan BBR pada multi-path routing mengalami peningkatan hampir 2 kali lipat dibandingkan dengan single path routing. Fenomena rata-rata throughput pada multi-path routing menunjukkan bahwa Reno, BIC, CUBIC, dan BBR tetap dapat memaksimalkan bandwidth yang tersedia pada multiple paths, walaupun terjadi packet reordering. Berdasarkan fenomena packet reordering dan rata-rata throughput pada multi-path routing, maka dilakukan observasi lebih lanjut kinerja algoritme TCP congestion control pada multi-path routing untuk evaluasi single flow dan multiple flow.

\subsection{Evaluasi Single Flow}

\section{A. Variasi Link delay}

Evaluasi single flow yang pertama adalah melakukan variasi link delay pada multiple paths. Gambar 3 menunjukkan perbandingan rata-rata throughput antara Reno, BIC, CUBIC, dan BBR pada variasi link delay $10 \mathrm{~ms}-100 \mathrm{~ms}$. Pada variasi link delay $10 \mathrm{~ms}$ - $100 \mathrm{~ms}$, rata-rata throughput Reno, BIC, CUBIC, dan BBR terus mengalami penurunan, tetapi tidak signifikan. Rata-rata throughput Reno, BIC, CUBIC, dan BBR tetap tinggi, yaitu di atas 18 Mbps. Fenomena rata-rata throughput pada variasi link delay $10 \mathrm{~ms}-100 \mathrm{~ms}$ menunjukkan bahwa Reno, BIC, CUBIC, dan BBR dapat memaksimalkan lebih dari $90 \%$ dari bandwidth yang tersedia pada multiple paths walaupun terjadi packet reordering.

Rata-rata throughput Reno, BIC, dan CUBIC, terus mengalami sedikit penurunan karena Reno, BIC, dan CUBIC menaikkan cwnd jika menerima ACK. Semakin tinggi link delay, semakin lama
Reno, BIC, dan CUBIC menerima ACK. Namun, karena BIC dan CUBIC menaikkan cwnd lebih agresif dibandingkan dengan Reno, maka penurunan rata-rata throughput BIC dan CUBIC lebih rendah dibandingkan dengan Reno.

Sementara itu, rata-rata throughput BBR tinggi karena BBR mengirimkan packet sebesar estimasi bottleneck bandwidth dan link delay pada multiple

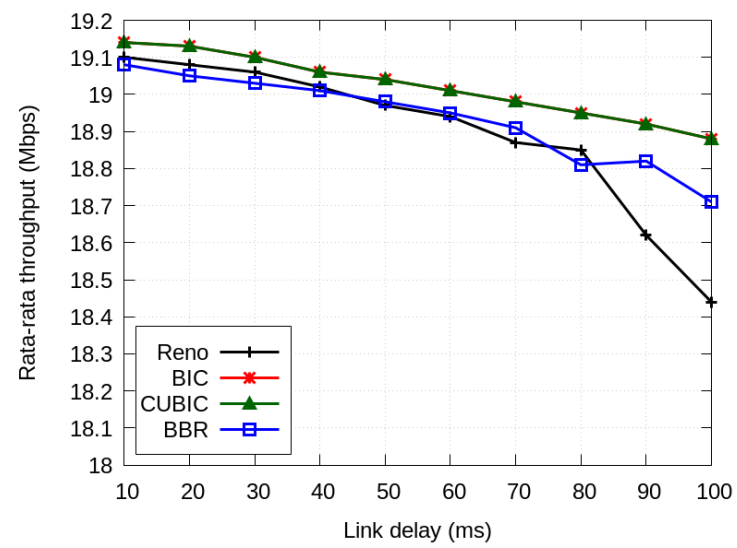

Gambar 3. Perbandingan throughput terhadap variasi link delay

paths. Namun, semakin tinggi link delay, semakin rendah estimasi bottleneck bandwidth karena BBR melakukan estimasi bottleneck bandwidth berdasarkan kecepatan penerimaan ACK. Oleh karena itu, rata-rata throughput BBR terus mengalami sedikit penurunan seiring bertambah tinggi link delay.

Namun, walaupun rata-rata throughput Reno, BIC, CUBIC, dan BBR sama-sama dapat mencapai di atas $18 \mathrm{Mbps}$, tetapi terdapat perbedaan pada ratarata RTT. Gambar 4 menunjukkan perbandingan rata-rata RTT antara Reno, BIC, CUBIC pada variasi link delay $10 \mathrm{~ms}-100 \mathrm{~ms}$. Pada semua variasi link delay, rata-rata RTT Reno, BIC, CUBIC, dan BBR cenderung lebih tinggi dari link delay. Namun, rata-rata RTT BBR sekitar $26 \mathrm{~ms}-58 \mathrm{~ms}$ lebih rendah dibandingkan dengan Reno, BIC, dan CUBIC. Fenomena rata-rata RTT yang lebih tinggi dari link delay menunjukkan bahwa Reno, BIC, CUBIC, dan BBR cenderung mengirimkan packet sampai mengisi buffer switch, sehingga dapat mengakibatkan queuing delay. Namun, karena BBR lebih sedikit mengisi packet ke dalam buffer, destination host BBR menerima packet lebih cepat hingga 58 ms dibandingkan dengan Reno, BIC, dan CUBIC.

Rata-rata RTT BBR lebih rendah dibandingkan dengan Reno, BIC, dan CUBIC disebabkan BBR menjaga ukuran cwnd sebesar estimasi BDP untuk mencegah mengisi packet terlalu banyak ke dalam buffer. Sebaliknya, Reno, BIC, dan CUBIC terus mengisi packet ke dalam buffer sampai penuh dan terjadi packet loss. Oleh karena itu, queuing delay Reno, BIC, dan CUBIC lebih tinggi dibandingkan dengan BBR. 


\section{B. Variasi Loss Rate}

Evaluasi single flow yang kedua adalah melakukan variasi loss rate pada multiple paths. Gambar 5 menunjukkan perbandingan rata-rata throughput Reno, BIC, CUBIC, dan BBR pada variasi loss rate $1 \%-10 \%$. Pada loss rate $1 \%$, ratarata throughput Reno, BIC, dan CUBIC mengalami penurunan sekitar $7 \mathrm{Mbps}$. Semakin tinggi loss rate, rata-rata throughput Reno, BIC, dan CUBIC terus

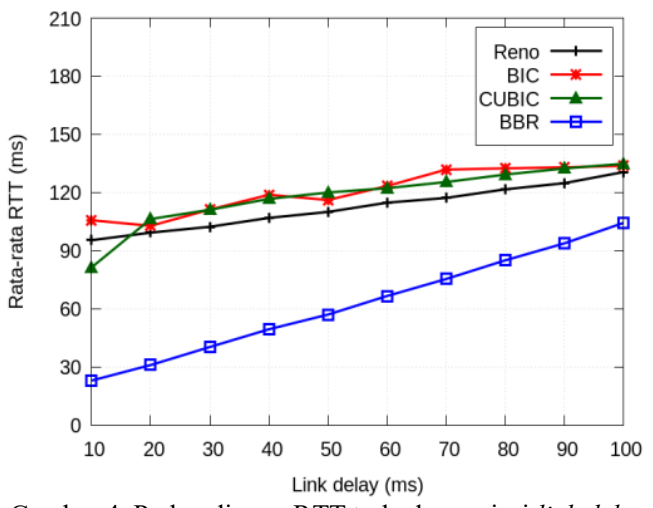

Gambar 4. Perbandingan RTT terhadap variasi link delay

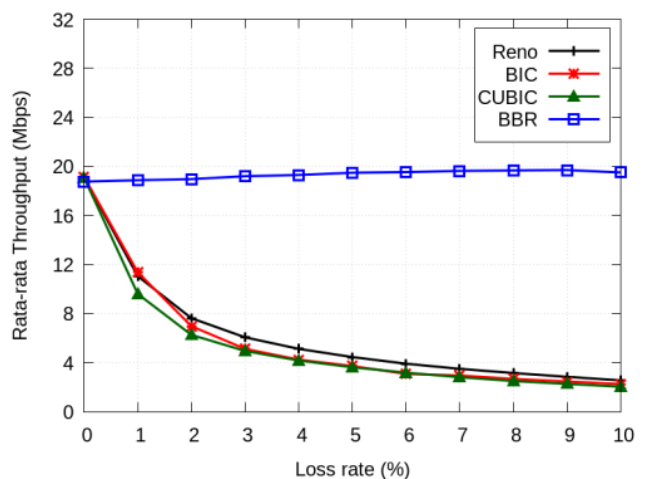

Gambar 5. Perbandingan throughput terhadap variasi loss rate

mengalami penurunan. Pada loss rate $10 \%$, rata-rata throughput Reno, BIC, dan CUBIC mengalami penurunan sekitar 17 Mbps. Sebaliknya, rata-rata throughput BBR tetap dapat mencapai 19 Mbps pada semua variasi loss rate. Fenomena rata-rata throughput pada variasi loss rate $1 \%-10 \%$ menunjukkan bahwa BBR tetap dapat memaksimalkan $95 \%$ bandwidth yang tersedia pada multiple paths walaupun pada loss rate $10 \%$. Sedangkan Reno, BIC, dan CUBIC hanya dapat memaksimalkan kurang dari 55\% bandwidth yang tersedia pada multiple paths untuk semua variasi loss rate. Hasil ini mengonfirmasi penelitian Cardwell, dkk. (2016b) yang dilakukan pada single path routing. Oleh karena itu, packet reordering yang terjadi pada multi-path routing tidak berdampak pada rata-rata throughput Reno, BIC, CUBIC, dan BBR untuk evaluasi loss rate.

Rata-rata throughput Reno, BIC, dan CUBIC mengalami penurunan disebabkan Reno, BIC dan CUBIC menurunkan cwnd secara drastis pada saat terjadi packet loss. Reno, BIC, dan CUBIC menurunkan cwnd sebelum mencapai kapasitas bandwidth maksimum jaringan. Semakin tinggi loss rate, semakin tinggi frekuensi Reno, BIC, dan CUBIC menurunkan cwnd. Oleh karena itu, rata-rata throughput Reno, BIC, dan CUBIC terus mengalami penurunan seiring bertambah tinggi loss rate.

Sebaliknya, BBR pada saat terjadi packet loss tidak menurunkan cwnd sedrastis Reno, BIC, dan CUBIC. Pada saat terjadi packet loss, BBR menjaga ukuran cwnd sebesar packet yang berhasil dikirimkan. Selain itu, pada saat retransmission selesai dilakukan, BBR langsung mengembalikan cwnd ke ukuran sebelum terjadi packet loss (Cardwell, dkk., 2017).

Pengukuran kinerja selanjutnya adalah rata-rata RTT Reno, BIC, CUBIC, dan BBR. Gambar 6 menunjukkan perbandingan rata-rata RTT Reno, BIC, CUBIC, dan BBR pada variasi loss rate $1 \%$ $10 \%$. Pada loss rate 1\%, rata-rata RTT Reno, BIC, dan CUBIC mengalami penurunan drastis menjadi sekitar 12 ms. Sebaliknya, rata-rata RTT BBR pada loss rate $1 \%$ tetap stabil pada sekitar $24 \mathrm{~ms}$. Kemudian, pada loss rate $2 \%-10 \%$, rata-rata RTT Reno, BIC, CUBIC, dan BBR cenderung stabil. Fenomena rata-rata RTT pada variasi loss rate 1\% $10 \%$ menunjukkan bahwa loss rate dapat mengakibatkan destination host Reno, BIC, dan CUBIC menerima packet lebih cepat dibandingkan dengan tanpa loss rate. Selain itu, loss rate juga dapat mengakibatkan destination host Reno, BIC, dan CUBIC menerima packet sekitar $12 \mathrm{~ms}$ lebih cepat dibandingkan dengan BBR.

Rata-rata RTT BBR lebih tinggi dibandingkan dengan Reno, BIC, dan CUBIC disebabkan BBR tetap dapat mengirimkan packet sampai kapasitas maksimum bandwidth jaringan walaupun pada loss rate $10 \%$. Oleh karena itu, rata-rata RTT BBR tetap stabil pada semua variasi loss rate. Sebaliknya, Reno, BIC, dan CUBIC mengalami packet loss sebelum bandwidth jaringan terisi penuh, sehingga rata-rata RTT Reno, BIC, dan CUBIC mengalami penurunan drastis. Oleh karena itu, walaupun selama 100 detik destination host Reno, BIC, dan CUBIC menerima packet lebih cepat dibandingkan dengan $\mathrm{BBR}$, tetapi destination host BBR menerima packet lebih banyak dibandingkan dengan Reno, BIC, dan CUBIC.

\subsection{Evaluasi Multiple Flow}

\section{A. Inter TCP Protocol Fairness}

Evaluasi multiple flow yang pertama adalah mengirimkan dua TCP flow dengan setiap TCP flow menggunakan algoritme TCP congestion control yang berbeda. Tabel 4 menunjukkan rata-rata throughput dan perhitungan Jain's fairness index dari kedua TCP flow. Pada semua evaluasi inter TCP protocol fairness, total rata-rata throughput kedua TCP flow mencapai 19 Mbps. Fenomena rata-rata throughput pada evaluasi inter TCP protocol fairness menunjukkan bahwa kedua TCP flow tetap 
dapat memaksimalkan $95 \%$ bandwidth yang tersedia pada multiple paths walaupun terjadi packet reordering.

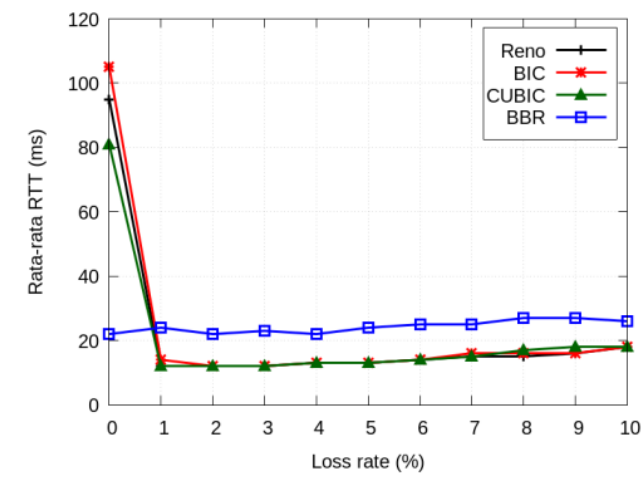

Gambar 6. Perbandingan RTT terhadap variasi loss rate

Tabel 4. Perbandingan inter TCP protocol fairness.

\begin{tabular}{ccccc}
\hline \multicolumn{2}{c}{ Source host 1 } & \multicolumn{2}{c}{ Source host 2 } & Jain's \\
\cline { 1 - 4 } TCP & $\begin{array}{c}\text { Through } \\
\text { put } \\
\text { (Mbps) }\end{array}$ & TCP & $\begin{array}{c}\text { Through } \\
\text { put } \\
\text { (Mbps) }\end{array}$ & $\begin{array}{c}\text { fairness } \\
\text { index }\end{array}$ \\
\hline CUBIC & 10.61 & Reno & 8.27 & 0.985 \\
BIC & 10.89 & CUBIC & 8.05 & 0.978 \\
BIC & 12.22 & Reno & 6.93 & 0.929 \\
BBR & 7.73 & CUBIC & 11.04 & 0.969 \\
BBR & 7.11 & Reno & 11.42 & 0.949 \\
BBR & 7.27 & BIC & 11.29 & 0.955 \\
\hline
\end{tabular}

Kemudian, jika melihat Jain's fairness index pada Tabel 4, Jain's fairness index pada semua pengujian inter TCP protocol fairness mencapai di atas 0.9. Namun, fairness CUBIC lebih tinggi dibandingkan dengan Reno, BIC, dan BBR. Jain's fairness index CUBIC dengan Reno, CUBIC dengan BIC, dan CUBIC dengan BBR paling mendekati nilai 1 dibandingkan dengan yang lainnya. Oleh karena itu, jika dua algoritme TCP congestion control mengirimkan packet secara bersamaan ke dalam multiple paths, CUBIC dapat berbagi throughput lebih adil dibandingkan dengan Reno, BIC, dan BBR.

Fairness CUBIC lebih tinggi dibandingkan dengan Reno, BIC, dan BBR karena CUBIC menggunakan mode TCP. Pada mode TCP, CUBIC mengirimkan packet dengan kecepatan yang sama dengan Reno. Oleh karena itu, fairness tertinggi terjadi pada saat CUBIC dengan Reno. Walaupun CUBIC mengirimkan packet sedikit lebih agresif dibandingkan dengan Reno, tetapi kondisi tersebut mengakibatkan fairness antara CUBIC dengan BIC lebih tinggi dibandingkan fairness antara Reno dengan BIC. Sementara itu, jika melihat rata-rata throughput BIC pada Tabel 4, BIC mengirimkan packet lebih agresif dibandingkan dengan Reno, CUBIC, dan BBR. BIC lebih agresif karena BIC mengirimkan packet dengan menggunakan mode scalability.

Sebaliknya, fairness BBR lebih ditentukan oleh ukuran buffer pada switch. Apabila ukuran buffer lebih besar dari 1.5 BDP, rata-rata throughput BBR lebih rendah dibandingkan dengan algoritme TCP congestion control berbasis packet loss (Cardwell, dkk.,2016b). Ukuran buffer yang digunakan pada

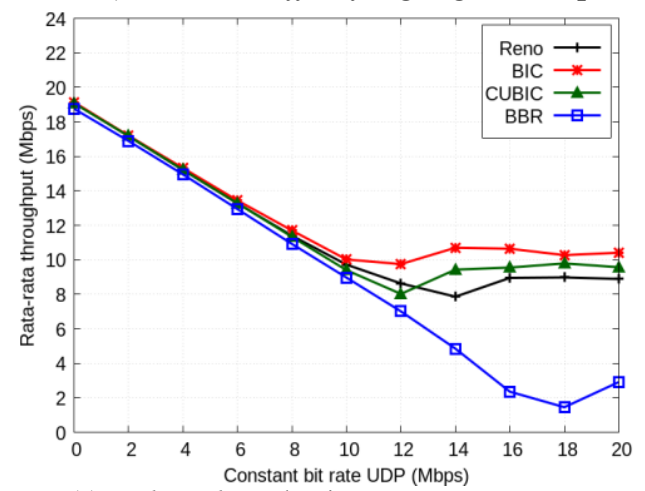

(a) Throughput algoritme TCP congestion control

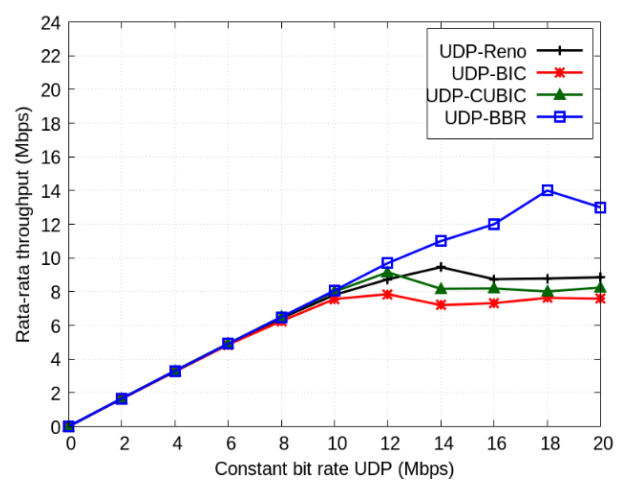

(b) Throughput UDP

Gambar 7. Perbandingan throughput TCP dan UDP

penelitian ini adalah 8 BDP. Oleh karena itu, ratarata throughput $\mathrm{BBR}$ lebih rendah dibandingkan dengan Reno, BIC, dan CUBIC untuk semua pengujian inter TCP protocol fairness BBR pada Tabel 4.

\section{B. Fairness Antara TCP dengan UDP}

Evaluasi multiple flow yang kedua adalah mengirimkan dua flow dengan setiap flow menggunakan protokol transport yang berbeda. Flow pertama adalah TCP flow dan flow kedua adalah UDP flow. Gambar 7 menunjukkan perbandingan rata-rata throughput Reno, BIC, CUBIC, BBR, dan UDP pada variasi CBR 2 Mbps 20 Mbps. Berdasarkan rata-rata throughput TCP pada Gambar 7 (a), pada CBR 2 Mbps - $10 \mathrm{Mbps,}$ rata-rata throughput Reno, BIC, dan CUBIC mengalami penurunan sebesar variasi CBR. Namun, pada CBR $12 \mathrm{Mbps}$ - $20 \mathrm{Mbps}$, rata-rata throughput Reno, BIC, dan CUBIC stabil pada sekitar 8 Mbps 10 Mbps. Sebaliknya, rata-rata throughput BBR pada CBR 2 Mbps - 20 Mbps terus mengalami penurunan hampir sebesar variasi CBR.

Fenomena rata-rata throughput TCP juga sama dengan rata-rata throughput UDP pada Gambar 7 (b). Pada CBR 2 Mbps - 10 Mbps, rata-rata throughput UDP pada Reno, BIC, dan CUBIC terus mengalami peningkatan. Namun, pada CBR 12 


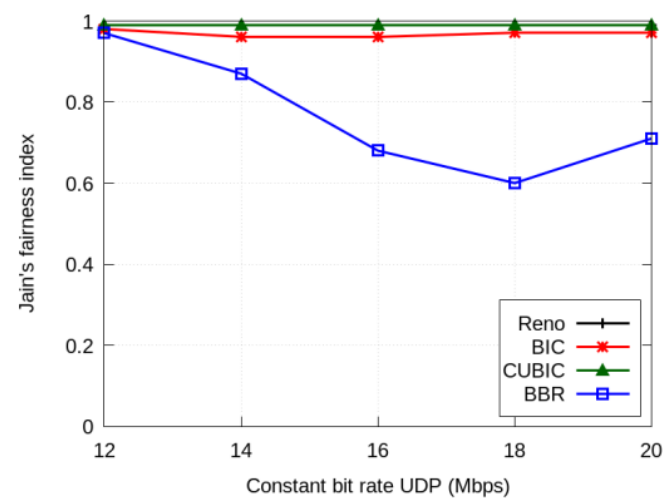

Gambar 8. Perbandingan fairness antara TCP dengan UDP.

Mbps - 20 Mbps, rata-rata throughput Reno, BIC, dan CUBIC stabil pada sekitar 7 Mbps - 9 Mbps. Sebaliknya, rata-rata throughput UDP pada BBR terus mengalami peningkatan pada semua variasi CBR. Fenomena rata-rata throughput TCP dan UDP menunjukkan bahwa pada CBR $2 \mathrm{Mbps}-10 \mathrm{Mbps}$, Reno, BIC, CUBIC, dan BBR sama-sama dapat berbagi throughput secara adil dengan UDP. Namun, pada CBR 12 Mbps - 20 Mbps, UDP lebih agresif dibandingkan dengan BBR. Sedangkan Reno, BIC, dan CUBIC pada CBR 12 Mbps - 20 Mbps tetap dapat berbagi throughput secara adil dengan UDP, walaupun rata-rata throughput Reno, BIC, dan CUBIC berbeda-beda. Oleh karena itu, untuk mengetahui algoritme TCP congestion control yang mendapatkan fairness paling tinggi, maka Jain's fairness index dihitung pada CBR 12 Mbps 20 Mbps.

Gambar 8 menunjukkan perbandingan Jain's fairness index Reno, BIC, CUBIC, dan BBR pada CBR 12 Mbps - 20 Mbps. Pada CBR 12 Mbps - 20 Mbps, Reno, BIC dan CUBIC mendapatkan fairness yang tinggi, yaitu di atas 0.9. Namun, Jain's fairness index Reno dan CUBIC paling mendekati 1, yaitu 0.99. Sedangkan pada BBR, Jain's fairness BBR pada CBR 14 Mbps - 20 Mbps di bawah 0.9. Oleh karena itu, Reno dan CUBIC lebih adil dalam berbagi throughput dengan UDP dibandingkan dengan BIC dan BBR.

Reno dan CUBIC mendapatkan fairness yang sama disebabkan CUBIC menggunakan mode TCP. Sedangkan BIC beroperasi dengan menggunakan mode scalability. Oleh karena itu, BIC mengirimkan packet lebih agresif dibandingkan dengan Reno dan CUBIC. Sementara itu, BBR mengirimkan packet berdasarkan estimasi dari bandwidth yang tidak digunakan oleh UDP. Oleh karena itu, rata-rata throughput $\mathrm{BBR}$ terus mengalami penurunan hampir sebesar CBR.

\section{KESIMPULAN}

Multi-path routing dapat mengakibatkan TCP Multi-path routing dapat mengakibatkan TCP packet reordering walaupun multiple paths menggunakan cost yang sama dan packet didistribusikan secara merata. Namun, packet reordering tidak berdampak pada penurunan rata-rata throughput yang signifikan. Pada single flow, BBR adalah algoritme TCP congestion control yang terbaik pada multipath routing. Namun, pada multiple flow, CUBIC adalah algoritme TCP congestion control yang terbaik pada multi-path routing.

Pada single flow, BBR lebih baik dalam memaksimalkan bandwidth yang tersedia pada multiple paths dibandingkan dengan Reno, BIC, dan CUBIC. Pada evaluasi link delay, Reno, BIC, CUBIC, dan BBR dapat memaksimalkan lebih dari $90 \%$ dari bandwidth yang tersedia pada multiple paths. Namun, rata-rata RTT BBR lebih rendah hingga 58 ms dibandingkan dengan Reno, BIC, dan CUBIC. Pada evaluasi loss rate, BBR tetap dapat memaksimalkan $95 \%$ dari bandwidth yang tersedia pada multiple paths, walaupun pada loss rate $10 \%$. Sedangkan Reno, BIC, dan CUBIC hanya dapat memaksimalkan kurang dari 55\% bandwidth yang tersedia pada multiple paths untuk semua variasi loss rate.

Pada mutliple flow, fairness CUBIC lebih tinggi dibandingkan dengan Reno, BIC, dan BBR. Pada evaluasi inter TCP protocol fairness, Jain's fairness index CUBIC paling mendekati nilai 1 dibandingkan dengan Reno, BIC, dan BBR. Sedangkan pada evaluasi fairness antara TCP dengan UDP, Jain's fairness index Reno dan CUBIC paling mendekati nilai 1 dibandingkan dengan BIC dan BBR.

\section{DAFTAR PUSTAKA}

ARROKKIAM, J. A., WU, X., BROWN, K. N. dan SREENAN, C. J., 2014. Experimental Evaluation of TCP Performance over 10Gb/s Passive Optical Networks (XGPON). In: IEEE Global Communications Conference, pp. 2223-2228.

BENNETT, J. C. R., PARTRIDGE, C. dan SHECTMAN, N., 1999. Packet Reordering is Not Pathological Network Behavior. IEEE/ACM Transactions on Networking, 7(6), pp. 789-798.

CARDWELL, N., CHENG, Y., GUNN, C. S., YEGANEH, S. H. dan JACOBSON, V., 2016a. BBR Congestion-Based Congestion Control. ACM Queue, 14(5), pp. 20-53.

CARDWELL, N., CHENG, Y., GUNN, C. S., YEGANEH, S. H. dan JACOBSON, V., 2016b. BBR Congestion Control, IETF 97. [online] Tersedia di: $<$ https://www.ietf.org/proceedings/97/slides /slides-97-iccrg-bbr-congestion-control02.pdf $>$ [Diakses 23 Juli 2019].

CARDWELL, N., CHENG, Y., YEGANEH, S. H. dan JACOBSON, V., 2017. BBR Congestion Control. Internet Congestion Control Research Group - Internet Draft. 
CARPA, R., DIAS DE ASSUNCAO, M., GLUCK, O., LEFEVRE, L. dan MIGNOT, J. -C., 2017. Evaluating the Impact of SDNInduced Frequent Route Changes on TCP Flows. In: 13th International Conference on Network and Service Management.

CHAITANYA, N. K. dan VARADARAJAN, S., 2016. Load distribution using multipathrouting in wired packet networks: A comparative study. Elsevier Perspectives in Science, 8, pp. 234-236.

CHENG, Y. dan CARDWELL, N., 2016. Making Linux TCP Fast, In: Netdev 1.2.

DIXIT, A., PRAKASH, P., HU, Y. C. dan KOMPELLA, R. R., 2013. On the Impact of Packet Spraying in Data Center Networks. In: IEEE INFOCOM, pp. 21302138.

HA, S. dan RHEE, I., 2008. Hybrid Slow Start for High-Bandwidth and Long-Distance Networks. In: PFLDNet.

HA, S., RHEE, I. dan XU, L., 2008. CUBIC: A New TCP-Friendly High-Speed TCP Variant. ACM SIGOPS Operating Systems Review - Research and developments in the Linux kernel, 42(5), pp. 64-74.

HOCK, M., BLESS, R. and ZITTERBART, M., 2017. Experimental Evaluation of BBR Congestion Control. In: IEEE 25th International Conference on Network Protocols (ICNP)

HUBERT, B., MAXWELL, G., MOOK, R., OOSTERHOUT, M., SCHROEDER, P. B. dan SPAANS, J., 2002. Linux Advanced Routing \& Traffic Control HOWTO. [online] Tersedia di: $<$ https://www.tldp.org/HOWTO/AdvRouting-HOWTO/lartc.loadshare.html> [Diakses 23 Juli 2019].

iPerf - The ultimate speed test tool for TCP, UDP and SCTP, n.d. [online] Tersedia di: $<$ https://iperf.fr/> [Diakses 23 Juli 2019.

JACOBSON, V., 1990. modified TCP congestion avoidance algorithm. End2end-interest mailing list.

JAIN, R. K., CHIU, D.-M. dan HAWE, W. R., 1984. A Quantitative Measure of Fairness and Discrimination for Resource Allocation in Shared Computer System. Technical Report TR-301, Digital Equipment Corporation.

KANAGEVLU, R. dan AUNG, K. M. M., 2015. SDN controlled Local re-routing to reduce congestion in cloud Data Centers. In: International Conference on Cloud Computing Research and Innovation, $\mathrm{pp}$. 80-88.

KARLSSON, J., HURTIG, P., BRUNSTROM, A.,
KASSLER, A. dan STASI, G. D., 2012. Impact of Multi-path Routing on TCP Performance. In: IEEE International Symposium on a World of Wireless, Mobile and Multimedia Networks.

KUROSE, J. F. dan ROSS, K. W., 2017. Computer Networking: A Top-Down Approach. 7th ed. New Jersey: Pearson.

KUZNETSOV, A. N., n.d. TBF - Token Bucket Filter. [online] Tersedia di: $<$ https://linux.die.net/man/8/tc-tbf $>$ [Diakses 23 Juli 2019].

LIU, J., LI, J., SHOU, G., HU, Y., GUO, Z. dan DAI, W., 2014. SDN Based Load Balancing Mechanism for Elephant Flow in Data Center Networks. In: International Symposium on Wireless Personal Multimedia Communications, pp. 486-490.

LUKASEDER, T., BRADATSCH, L., ERB, B., HEIJDEN, R. W. V. D. dan KARGL, F., 2016. A Comparison of TCP Congestion Control Algorithms in $10 \mathrm{G}$ Networks. In: IEEE 41st Conference on Local Computer Networks, pp. 706-714.

NetEM, n.d. [online] Tersedia di: $<$ https://wiki.linuxfoundation.org/networkin $\mathrm{g} /$ netem $>$ [Diakses 23 Juli 2019].

ROS, D. dan WELZL, M., 2013. Less-than-BestEffort Service: A Survey of End-to-End Approaches. IEEE Communications Surveys and Tutorials, 15(2), pp. 898-908.

SINGH, S. K., DAS, T. dan JUKAN, A., 2015. A Survey on Internet Multipath Routing and Provisioning. IEEE Communications Surveys and Tutorials, 17(4), pp. 21572175.

Tcpdump, n.d. [online] Tersedia di: $<$ https://www.tcpdump.org $>$ [Diakses 23 Juli 2019].

VirtualBox, n.d. [online] Tersedia di: $<$ https://www.virtualbox.org/> [Diakses 23 Juli 2019].

XU, L., HARFOUSH, K. dan RHEE, I., 2004. Binary Increase Congestion Control (BIC) for Fast, Long-Distance Networks. In: INFOCOM, pp. 2514-2524.

YUE, Z., ZHANG, X., REN, Y., LI, J. dan ZHONG, Q., 2012. The Performance Evaluation and Comparison of TCP-based High-speed Transport Protocols. In: IEEE 3rd International Conference on Software Engineering and Service Science, pp. 509512. 